\title{
GLUTENSİZ NUGGETLARDA LİPOLİTİK DEĞİŞİMLER ÜZERİNE DONMUŞ DEPOLAMANIN ETKİSI
}

\author{
Esra Selin Davarcioğlu, Eda Demirok Soncu* \\ Ankara Üniversitesi, Mühendislik Fakültesi, Gıda Mühendisliği Bölümü, Ankara, Türkiye
}

Geliş / Received: 23.11.2020; Kabul / Accepted: 24.12.2020 Online bask1 / Published online: 12.01.2021

Davarcıoğlu, E. S., Demirok Soncu, E. (2021). Glutensiz nuggetlarda lipolitik değişimler üzerine donmuş depolamanın etkisi.GID $A$ (2021) 46 (1) 201-215 doi: 10.15237/gida.GD20100

Davarcoğlu, E. S., Demirok Soncu, E. (2021). Effect of frozen storage on lipolytic changes in gluten-free nuggets.GIDA (2021) 46 (1) 201-215 doi: 10.15237/gida.GD20100

\section{ÖZ}

Çölyak hastalı̆̆, yaşam boyu süren ve gluten intolerasına sahip bireylerde buğday, arpa ve çavdar tüketimi sonucu bağırsaklarda gelişen iltihaplanma nedeniyle malabsorbsiyonla sonuçlanan bir hastalıktır. Tedavisi bir ömür glutensiz diyet olan bu hastalığa sahip bireylerin yaşamını kolaylaştırmak ve hayat kalitesini artırmak için ürün çeşitliliğinin de arttırlması ve raf ömrüne ilişkin kalite çalışmalarının yapılması önemlidir. Bu noktadan hareketle, çalışma kapsamında sıvı sos kaplamasında farklı oranlarda pirinç unu, mısır unu ve mısır nişastası kullanılarak üretilen ve donuk depolanan $\left(-18^{\circ} \mathrm{C}, 6\right.$ ay) glutensiz nuggetlarda lipitlerde meydana gelen değişimler incelenmiştir. Donmuş depolama süresince serbest yağ asitliği (SYA) ve tiyobarbitürik asit reaktif madde (TBARM) değerlerinin arttuğı, konjuge dien ve konjuge trien değerlerinin ise azalış gösterdiği tespit edilmiştir $(P<0.05)$. Depolamanın başlangıcında en yüksek değerine ulaşan hekzanal miktarı ise sonrasında azalış göstermiş ve depolamanın son günlerinde tekrar artışa geçmiştir. Farklı bileşimde sıvı sos kullanımının ise incelenen parametreler üzerine etkisi bulunamamıştır $(P>0.05)$. Sonuçlar, donuk olarak depolanan glutensiz nuggetlann 6 ay süresince güvenle tüketilebileceğini göstermiştir.

Anahtar kelimeler:Kaplamalı piliç ürünleri, lipoliz, lipit oksidasyonu, pirinç unu, mısır unu, mısır nişastası, siv1 sos

\section{EFFECT OF FROZEN STORAGE ON LIPOLYTIC CHANGES IN GLUTEN- FREE NUGGETS}

\begin{abstract}
Celiac disease, a lifelong disorder, is induced by the intake of gluten proteins present in wheat, barley and rye and results in malabsorption due to inflammation of intestine in gluten intolerant individuals. The treatment is lifelong adherence to a gluten-free diet. Therefore, enhancing variety of gluten-free food products and performing quality analysis regarding shelf life is crucial to increase life quality and to make easy the life for individuals with celiac. From this point of view, lipolytic changes were investigated in frozen stored $\left(-18^{\circ} \mathrm{C}\right.$ for 6 months) gluten-free chicken nuggets coated with batter, which was produced by using different ratio of rice flour, corn flour and corn starch. Free fatty acids (FFAs) and thiobarbituric acid reactive substance (TBARS) values increased whereas conjugated dien and conjugated trien values decreased with increasing storage time $(P<0.05)$. Hexanal amount reached to the maximum level at the beginning of storage followed by a decrease in the middle of
\end{abstract}

*Yazışmalardan sorumlu yazar / Corresponding author

\edemirok@eng.ankara.edu.tr

(C): (+90) 3122033639

용: (+90) 3123178711

Esra Selin Davarcıŏlu; ORCID no: 0000-0001-9500-5354

Eda Demirok Soncu; ORCID no: 0000-0003-0997-5835 
storage and then an increase at the end of storage. The use of batter with different formula did not affect parameters evaluated $(P>0.05)$. Results demonstrated that gluten-free chicken nuggets should be consumed within 6 months under frozen storage conditions.

Keywords: Coated chicken meat products, lipolysis, lipid oxidation, rice flour, corn flour, corn starch, batter

\section{GİRIŞ}

Çölyak hastalı̆̆ı, en basit ifadeyle genetik yatkınlığ1 olan ve gluten intoleransına sahip bireylerde buğday, arpa ve çavdar gibi gluten içeren tahılların tüketimi sonucu ortaya çıan ve yaşam boyu süren bağışıklık sistemi hastalı̆̆ıdır (Catassi ve Fasano, 2008; Niewinski, 2008). Buğdayın depo proteini olarak bilinen gluten proteininin alkolde çözünen fraksiyonu gliadin, çölyaklı bireyler için toksiktir. Benzer şekilde arpada hordein, çavdarda ise sekalin çölyaklı bireyler için toksik olan prolaminlerdir (Niewinski, 2008; Özugur ve Hayta, 2011). Çölyaklı bireylerde, gluten tüketimine bağlı bağırsak mukozasında ortaya çıkan iltihaplanma nedeniyle ince bağırsak zarında yer alan villuslar hasar görerek küçülür ve zamanla kaybolurlar. Aynı zamanda besin öğelerinin de emiliminden sorumlu olan villuslarda ortaya çıkan bu tahribat zamanla bağırsak yüzey alanının azalmasi, demir ve kalsiyum gibi mineraller ile A, $\mathrm{D}, \mathrm{E}, \mathrm{K}$ vitaminleri ve folik asitin emilememesine neden olur (Niewinski, 2008; Jnawali vd., 2016). Çölyak hastalığının klinik belirtileri kişiden kişiye değişmekle birlikte genellikle karında şişlik ile birlikte kramp şeklinde gelen ağın, gastroözofajiyal reflü, diyare ya da kabızlık, kilo kaybı, kemiklerde gelişen hastalıklar, kansızlık ve zayıflıktır (Rodrigo, 2006). Uzun vadede ise çölyak hastalığının kemik erimesi, kısırlık ve kanser gibi hastalıklara zemin hazırladığ (Catassi ve Fasano, 2008).

Avrupa ve ABD'de yapılan çalışmalar, çölyaklı bireylerin toplam popülasyonun $\% 1$ 'ini oluşturduğunu göstermiştir (Niewinski, 2008). T.C. Sağlık Bakanlığı Halk Sağlığı verilerine göre ülkemizde çölyak görülme sıklığ1 0.3-\%1 arasında değişmektedir. 2019 yllında tanı konmuş hasta sayıs1 68123 olup çölyaklı bireylerin ancak \%10'una tanı konulabildiği öngörülmektedir (Anonymous, 2017). Sağlıklı bir yaşam için çölyak hastalığının bilinen tek tedavi yöntemi ise glutenin diyetten tamamen çıkarılması ve glutensiz yaşam biçiminin oluşturulmasıdır (Rodrigo, 2006;
Niewinski, 2008). Son zamanlarda çölyak hastalı̆̆ına sahip olmayan bireyler de kilo kontrolü ve sağllklı yaşam tercihleri doğrultusunda glutensiz beslenmeye doğru yönelmişlerdir (Kerimoğlu ve Serdaroğlu, 2019). Bu noktada, oldukça yüksek popülasyona sahip çölyaklı bireyler ve tercihen glutensiz beslenmek isteyen tüketiciler için sağlıklı, güvenilir, lezzetli, çeşitlendirilmiş ve kolay ulaşılabilir glutensiz gıdalara ihtiyaç duyulduğu apaçık ortadadır. Günümüzde bu konudaki farkındalık artmış ve hem marketlerde hem de e-ticarette glutensiz ekmek, pizza, makarna, tahıl unları ve tatllar gibi oldukça farklı kategorilerde glutensiz ürünler ulaşılabilir hale gelmiştir (Niewinski, 2008). Yapılan bir çalışmada, 2013-2015 yılları arasında artan talebi karşlamak amacıyla glutensiz ürün üretimi yapan bir sektörde \%136 büyüme belirlenmiştir (Kerimoğlu ve Serdaroğlu, 2019).

Et ve et ürünlerinin, kaliteli ve dengeli beslenmedeki rolü büyüktür. İşlenmemiş et, piliç eti ve balık çölyaklı bireylerin diyetinde yerini alırken, bu bireyler sosis salam gibi şarküteri ürünleri ile nugget, şinitzel gibi kaplamalı ileri işlem piliç ürünlerini gluten riski sebebiyle tüketememektedir. Bu noktada, ürün çeşitliliğini arttırmanın yanı sıra özellikle zaman yönetiminin önemli olduğu günümüz şartlarında tüketime hazır ürünlerden nuggetın glutensiz opsiyonlarının geliştirilmesine ilişkin çalışmalar son zamanlarda ön plana çıkmışır. Nugget, hazırlanan et hamuruna şekil verildikten sonra ilk aşamada sıvı sos ve ardindan kuru sos ile kaplanan, kısa süreli kızartma sonrası buharlı fırında pişirilerek tüketime hazır hale getirilen bir üründür (Soncu, 2014). Çölyaklı bireyler için nuggetlardaki en büyük risk kaplamanın gluten içermesi olup, bu noktada glutensiz nugget üretimi için gluten içermeyen sıvı ve kuru sosların formüle edilmesi önem kazanmıştır.

Ürün geliştirmenin yanı sıra glutensiz nuggetlarda raf ömrü boyunca kalite parametrelerinde 
değişimin izlenmesi tüketicilere kaliteli ve güvenli ürün sunmak açısından önemlidir. Nugget gibi kaplamalı piliç ürünlerinde raf ömrünü sınırlayan en önemli faktör lipolitik değişimlerdir. Et ve et ürünlerinde lipolitik değişimler lipoliz reaksiyonları ve lipit oksidasyonu ile açıklanır. Lipoliz reaksiyonlan, trigliserit ya da fosfolipitlerin esteraz (lipaz ve fosfolipaz) enzimleri aracilğıyla monogliseritlere, digliseritlere ya da serbest yağ asitlerine parçalanması olarak tanımlanır (Gandemer, 2002). Başlangıç, gelişme ve sonuç olmak üzere 3 farklı aşamadan oluşan lipit oksidasyonu ise ette doğal olarak bulunan ya da lipoliz reaksiyonları sonucu oluşan serbest yağ asitlerinin oksijen varllğında otokatalitik olarak ilk aşamada peroksitler, hidroperoksitler, konjuge dien/trien gibi birincil oksidasyon ürünlerine parçalanması olarak ifade edilir. Bu bileşikler stabil olmayıp, etlerde kötü tat ve koku oluşumuna neden olan ikincil oksidasyon ürünlerine (hidrokarbonlar, aldehitler, alkoller, ketonlar, esterler ve asitler) hızla dönüşürler (Amaral vd., 2018; Dominguez vd., 2019). Is1l işlem lipolitik reaksiyonları tetikleyen faktörlerden biri olup, nugget gibi kaplamalı piliç ürünlerinin üretim prosesinde yer alan 1sıl işlem basamağ1, hücre duvarının parçalanması sonucu oksijen ve heme-demir salınımının artmasına, serbest radikal oluşumunun tetiklenmesine ve sonuç olarak bu tip ürünlerin lipit oksidasyonuna karşı daha duyarlı hale gelmesine neden olur (Cagdas ve Kumcuoglu, 2015; Amaral vd., 2018). Ayrica lipit oksidasyonu renk, görünüş ve tekstürün olumsuz yönde etkilenmesine, besinsel değerin azalmasına, toksik bileşiklerin yanı sıra ransit tat ve koku oluşumuna sebep olur (Amaral vd., 2018; Dominguez vd., 2019).

Misır, pirinç, sorgum, tef, kinoa, amarant, karabuğday gibi tahıllar ile bezelye, nohut, mercimek, soya ve keçiboynuzu glutensiz ürün üretmek amaciyla kullanilabilecek alternatif kaynaklardır (Jnawali vd., 2016). Literatürde, amarant (de Carvalho vd., 2018; Tamsen vd., 2018), pirinç unu (Jackson vd., 2006; Pinkaew ve Naivikul, 2019), pirinç ve mısır unu (Davarcioglu ve Kolsarici, 2019), sorgum unu (Devatkal vd., 2011), glutensiz buğday unu (Tașbaș vd., 2016), amarant ve kinoa unu (Verma vd., 2019) kullanılarak glutensiz nugget üretimine ilişkin kaynaklar mevcut olup bu araştırmalarda bazı kalite parametrelerine ilişkin değerlendirmeler de yapılmıştır. Bu makalede ise, yapılan geniş çaplı formülasyon çalışması sonrası seçilen en başarılı üç glutensiz sivı sos formülasyonu kullanılarak üretilen nuggetlarda lipolitik değişimlerin detaylı incelenmesi hedeflenmiştir. $\mathrm{Bu}$ noktadan hareketle, siv1 sos bileşiminde farklı oranlarda mısır ve pirinç unu ile mısır nişastası kullanılarak glutensiz piliç nuggetlar üretilmiş ve 6 ayllk donmuş depolama sürecinde lipitlerde meydana gelen lipoliz ve oksidasyon reaksiyonlarına ilişkin analizler yapılmıstır.

\section{MATERYAL VE YÖNTEM}

\section{Glutensiz piliç nugget üretimi ve depolama koşulları}

Glutensiz nugget üretimi Bolu'da ticari olarak üretim yapan bir entegre tavukçuluk üretim tesisinde gerçekleştirilmiştir. Araşurmada 3 farkl1 s1v1 sos bileşimine sahip glutensiz nugget üzerinde çalışılmış olup, nugget üretiminde kullanılan et hamuru, glutensiz siv1 sos ve glutensiz kuru sos formülasyonları Çizelge 1'de verilmiştir. Glutensiz sıvı sos bileşimlerine yapılan ön çalışmalarda 28 farklı formülasyon arasından seçim yapılarak karar verilmiş ve bu sürece ilişkin detaylı bilgiler Davarcioglu ve Kolsarici (2019) tarafindan aktarılmıştır.

Nugget üretiminin ilk aşamasında piliç göğüs eti 5 $\mathrm{mm}$, piliç göğüs ve but deri ise $1.3 \mathrm{~mm}$ ayna çapına sahip kıyma makinasında (Tefal, Hachoir 1500 Watt) hazırlanmıştır. Piliç eti, deri, su, ürüne özgü baharat karışımı (Spice mix tasty AG, Dutch Protein and Services Ingredients for the Food Industry (DPS), Holland) ve bağlayıcı (Binding AF V2, DPS, Holland) elde yoğurularak et hamuru hazırlanmıştrr. Hamur, piliç nugget kalıpları kullanılarak şekillendirildikten sonra hamurunun sertleşmesi için bir süre buzdolabında bekletilmiştir. Üç farklı formülasyona sahip glutensiz s1v1 sos (GSS1, GSS2, GSS3) 1:2 (sos:su, w/w) oranında sulandırılmış ve mikserde (Arzum Proset 444) karışturlarak homojen hale getirilmiştir. Nugget hamuru ilk önce glutensiz s1vi sos ardından glutensiz kuru sos ile manuel kaplandıktan sonra kaplamanın ete fiksasyonu için 
$180^{\circ} \mathrm{C}$ 'de 30 sn süreyle ayçiçek yağında fritözde (Bosch TFB3201, Germany) kızartılmıştur. Her bir grup için fritözdeki yağ değiştirilerek kullanılmışır. Kızartmayı takiben gluten bulaşısını engellemek amaciyla önceden özel olarak temizlenen buharlı firin hattı (CPS Cook Star, Holland) kullanılarak nuggetlar iç sıcaklığ $174^{\circ} \mathrm{C}^{\prime}$ ye ulaşıncaya kadar $\% 70$ buhar altında ve $150^{\circ} \mathrm{C}$ sıcaklıkta 4 dakika süreyle pişirilmiştir. Buharlı firın hattını takiben nuggetlar $-40^{\circ} \mathrm{C}$ 'deki spiral dondurucuda (CPS Tempo Fost, Holland) merkez sıcaklığ $-18^{\circ} \mathrm{C}$ 'ye ulaşıncaya kadar hızla dondurulmuştur. Donuk nuggetlar 10'arlı olarak polipropilen tabaklara yerleştirilmiş ve PVC streç film kullanılarak aerobik koşullarda ambalajlanmıştr. Piliç nuggetlar $-18^{\circ} \mathrm{C}$ 'de 6 ay süreyle depolanmış ve aylık periyotlarda her bir grubu temsilen bir ambalaj $4^{\circ} \mathrm{C}^{\prime} \mathrm{de}$ çözündürüldükten sonra analizler yapılmıştır. Deneme 3 farklı zamanda 3 tekerrürlü olarak kurulmuş ve analizler her bir tekerrür için iki paralel olacak şekilde yürütülmüştür.

Çizelge 1.Et hamuru, glutensiz sıv1 sos ve glutensiz kuru sos formülasyonları Table 1. Formulations for meat batter, gluten-free batter and gluten-free breader

\begin{tabular}{|c|c|c|c|c|}
\hline \multirow{2}{*}{$\begin{array}{l}\text { Et hamuru } \\
\text { Meat batter }\end{array}$} & \multicolumn{3}{|c|}{$\begin{array}{c}\text { Glutensiz siv1 sos (GSS)\# } \\
\text { Gluten-free batter }\end{array}$} & \multirow{2}{*}{$\begin{array}{c}\text { Glutensiz kuru sos } \\
\text { Gluten-free breader }\end{array}$} \\
\hline & GSS1 & GSS2 & GSS3 & \\
\hline $\begin{array}{c}\text { \%74.50 Piliç göğüs eti } \\
\% 74.50 \text { Chicken breast } \\
\text { meat }\end{array}$ & $\begin{array}{l}\text { \%30 Pirinç unu } \\
\% 30 \text { Rice flour }\end{array}$ & $\begin{array}{l}\% 40 \text { Pirinç unu } \\
\% 40 \text { Rice flour }\end{array}$ & $\begin{array}{l}\% 40 \text { Pirinç unu } \\
\% 40 \text { Rice flour }\end{array}$ & $\begin{array}{l}\text { \%40 Pirinç unu } \\
\text { \%40 Rice flour }\end{array}$ \\
\hline $\begin{array}{l}\% 6.2 \text { Piliç deri } \\
\% 6.2 \text { Chicken skin }\end{array}$ & $\begin{array}{l}\text { \%70 Misir unu } \\
\% 70 \text { Corn flour }\end{array}$ & $\begin{array}{l}\% 60 \text { Misir unu } \\
\% 60 \text { Corn flour }\end{array}$ & $\begin{array}{l}\% 60 \text { Misir unu } \\
\% 60 \text { Corn flour }\end{array}$ & $\begin{array}{l}\% 40 \text { Misir unu } \\
\% 40 \text { Corn flour }\end{array}$ \\
\hline $\begin{array}{l}\% 12.4 \mathrm{Su} \\
\% 12.4 \text { Water }\end{array}$ & $\begin{array}{l}\% 15 \text { Misir nişastas1 } \\
\% 15 \text { Corn starch }\end{array}$ & $\begin{array}{l}\% 5 \text { Misir nişastas1 } \\
\% 5 \text { Corn starch }\end{array}$ & $\begin{array}{l}\% 15 \text { Misir nişastas1 } \\
\% 15 \text { Corn starch }\end{array}$ & $\begin{array}{l}\% 3-5 \text { Maya } \\
\% 3-5 \text { Yeast }\end{array}$ \\
\hline $\begin{array}{l}\text { \%1.6 Baharat karışımı* } \\
\text { \%1.6 Spice mix* }\end{array}$ & $\begin{array}{l}\% 0.5 \mathrm{KMS}^{* * *} \\
\% 0.5 \mathrm{CMC}^{* * *}\end{array}$ & $\begin{array}{l}\% 0.5 \mathrm{KMS} \\
\% 0.5 \mathrm{CMC}\end{array}$ & $\begin{array}{l}\% 0.5 \mathrm{KMS} \\
\% 0.5 \mathrm{CMC}\end{array}$ & $\begin{array}{l}\% 5-10 \text { Şeker } \\
\% 5-10 \text { Sugar }\end{array}$ \\
\hline $\begin{array}{l}\% 5.3 \text { Bağlayıc1** } \\
\% 5.3 \text { Binding** }\end{array}$ & $\begin{array}{l}\% 0.2 \text { Ksantangum } \\
\% 0.2 \text { Xanthangum }\end{array}$ & $\begin{array}{l}\% 0.2 \text { Ksantangum } \\
\% 0.2 \text { Xanthangum }\end{array}$ & $\begin{array}{l}\% 0.2 \text { Ksantangum } \\
\% 0.2 \text { Xanthangum }\end{array}$ & $\begin{array}{l}\% 2-5 \text { Tuz } \\
\% 2-5 \text { Salt }\end{array}$ \\
\hline & $\begin{array}{l}\% 0.2 \text { Sakkaroz } \\
\% 0.2 \text { Saccharose }\end{array}$ & $\begin{array}{l}\% 0.2 \text { Sakkaroz } \\
\% 0.2 \text { Saccharose }\end{array}$ & $\begin{array}{l}\% 0.2 \text { Sakkaroz } \\
\% 0.2 \text { Saccharose }\end{array}$ & $\begin{array}{l}\% 2-5 \text { Ayçiçek yağ1 } \\
\% 2-5 \text { Sunflower oil }\end{array}$ \\
\hline & $\begin{array}{l}\% 2.5 \text { Tuz } \\
\% 2.5 \text { Salt }\end{array}$ & $\begin{array}{l}\% 2.5 \text { Tuz } \\
\% 2.5 \text { Salt }\end{array}$ & $\begin{array}{l}\% 2.5 \text { Tuz } \\
\% 2.5 \text { Salt }\end{array}$ & $\begin{array}{l}<\% 2 \text { Emülgatör } \\
<\% 2 \text { Emulsifier }\end{array}$ \\
\hline & $\begin{array}{l}\% 1 \text { Baharat } \\
\text { karışımı } \\
\% 1 \text { Spice mix }\end{array}$ & $\begin{array}{l}\% 1 \text { Baharat } \\
\text { karışımı } \\
\% 1 \text { Spice mix }\end{array}$ & $\begin{array}{l}\% 1 \text { Baharat } \\
\text { karıșimı } \\
\% 1 \text { Spice mix }\end{array}$ & $\begin{array}{c}<\% 2 \\
\text { Renklendirici } \\
<\% 2 \text { Coloring agent }\end{array}$ \\
\hline
\end{tabular}

\footnotetext{
*Baharat karışımı soğan tozu, sarımsak tozu ve kimyon içermektedir. / *Spice mix includes onion powder, garlic powder and cumin.

**Bağlayıcı bezelye lifi, bambu, patates ve pirinç içermektedir. / **Binding includes green pea fiber, bamboo, potato and rice.

***KMS:Karboksimetilselüloz / ***CMC:Carboxymethylcellulose

\#:Glutensiz sıvı soslar hazırlanırken mısır nişastası, KMS, ksantan gum, sakkaroz, tuz ve baharat karışımı $100 \mathrm{~g}$ un üzerinden hesaplanarak eklenmiştir. / Amount of corn starch, CMC, xanthan gum, saccharose, salt and spice mix are calculated for $100 \mathrm{~g}$ of flour during gluten-free batter preparation.
} 


\section{Besinsel bileşim analizleri}

Nugget örnekleri homojen hale getirildikten sonra AOAC (2010a)'de belirtilen yöntemlere göre nem (metot no:950.46), kül (metot no:920.153), soxhelet ekstraksiyon yöntemine göre yağ (metot no:991.36) ve Kjeldahl yöntemine göre protein (metot no:955.04) analizleri yapılmış ve sonuçlar $\%$ olarak hesaplanmıştır.

\section{Gluten analizi}

Gluten analizi akredite bir laboratuvarda ELISA yöntemine göre yapılmıştır (AOAC, 2010b). İlk aşamada $5 \mathrm{~g}$ örnek homojen hale getirildikten sonra $0.25 \mathrm{~g}$ tartulmış ve üzerine $2.5 \mathrm{ml}$ Cocktail çözeltisi ilave edilmiştir. Su banyosunda $\left(50^{\circ} \mathrm{C}\right) 40$ dakika inkübasyonu takiben örnekler hızla soğutulmuş ve üzerine $7.5 \mathrm{ml} \% 80$ etanol ilave edilerek 1 saat süreyle karıştırılmıştır. Santrifüj sonrası supernatant 1:12.5 oranında seyreltilmiş dilüsyon çözeltisi ile seyreltilmiştir. Analiz için gerekli sayıda kuyucuk okuyucuya yerleştirildikten sonra her bir kuyucuk $100 \mu \mathrm{l}$ ylkama çözeltisi ile 3 defa yıkanmıştır. Ardından her bir kuyucuğa 100 $\mu \mathrm{l}$ seyreltilmiş konjugat pipetlenip, 30 dakika oda sıcaklı̆̆ında inkübasyon sonrası kuyucuklar $250 \mu \mathrm{l}$ yıkama çözeltisi ile 3 defa daha yıkanmıştır. Her bir kuyucuğa $50 \mu \mathrm{l}$ substrat ve $50 \mu \mathrm{l}$ kromojen pipetlendikten sonra oda sicakliğında ve karanlıkta örnekler 30 dakika inkubasyona bırakılmış, her bir kuyucuğa $100 \mu$ l stop çözelti pipetlenerek hafifçe çalkalanmış ve ELISA okuyucusu ile $450 \mathrm{~nm}$ dalga boyunda okuma yapılmışur. Sonuçlar $\mathrm{mg} / \mathrm{kg}$ olarak verilmiştir.

\section{SYA analizi}

Analizin ilk aşamasında homojen nugget örneklerinden soğuk ekstraksiyon yöntemi ile ham yağ elde edilmiştir (Bligh ve Dyer, 1959). Yaklaşı 1 gram yağ örneği $10 \mathrm{ml}$ nötralize etil alkol içerisinde çözündürüldükten sonra $0.05 \mathrm{~N}$ $\mathrm{NaOH}$ kullanılarak titre edilmiş ve nugget örneklerinin \%SYA miktarı oleik asit cinsinden hesaplanmıştır (Mauriello vd., 2004).

\section{Özgül soğurma ( $\mathbf{K}_{232}$ ve $\left.\mathbf{K}_{270}\right)$ değerleri}

Konjuge dien ve konjuge trien bileşik miktarının belirlenmesi amacıyla yapılan özgül soğurma değerleri analizi Kıralan (2010) tarafindan rapor edildiği gibi AOCS metot no Ch5-91'e göre modifiye edilerek yürütülmüştür. Konjuge dien
$\left(\mathrm{K}_{232}\right)$ ve konjuge trien $\left(\mathrm{K}_{270}\right)$ değerlerinin hesaplanması için soğuk ekstraksiyon yöntemiyle ekstrakte edilen yağ örneğinden yaklaşı $0.02 \mathrm{~g}$ tartılarak $20 \mathrm{ml}$ hekzan içerisinde çözdürülmüştür. Çözeltinin absorbansı konjuge dien değeri için 232 nm'de, konjuge trien değeri için de 270 nm'de spektrofotometrik olarak (Perkin Elmer UV/VIS Spectrophotometer Lambda 35, USA) ölçülmüş ve hesaplama denklem 1'e göre yapılmıştır.

$$
\mathrm{K} \lambda=\frac{\mathrm{E} \lambda}{\mathrm{C} \times \mathrm{S}} \quad \text { Denklem } 1
$$

$\mathrm{K}_{\lambda}=232$ ya da $270 \mathrm{~nm}$ 'deki özgül soğurma değeri $\mathrm{E}_{\lambda}=232$ ya da $270 \mathrm{~nm}$ 'de okunan absorbans değeri $\mathrm{C}=$ Çözeltinin konsantrasyonu $(\mathrm{g} / 100 \mathrm{ml})$

$\mathrm{S}=$ Işık yolu uzunluğu $(\mathrm{cm})$

\section{TBARM sayis1}

TBARM say1s1 Mielnik vd. (2006) tarafindan rapor edilen yönteme göre belirlenmiştir. Yaklaşık $10 \mathrm{~g}$ homojen nugget örneği $30 \mathrm{ml}$ triklor asetik asit $(\% 7.5 \mathrm{w} / \mathrm{v})$ içerisinde ultraturrax (Miccra D9, Germany) kullanilarak homojenize edildikten sonra örnekler $10000 \mathrm{~d} / \mathrm{d}$ 'da 5 dak süreyle santrifüjlenmiştir (Hermle Z326K, Germany). Süpernatant, Whatman No:40 filtre kağıdından süzüldükten sonra $5 \mathrm{ml}$ süzüntü vidalı kapaklı cam test tüplerine aktarilmış ve üzerine $5 \mathrm{ml} \mathrm{2-}$ tiyobarbitürik asit çözeltisi $(0.02 \mathrm{~mol} / \mathrm{L}, 0.1 \mathrm{~N}$ $\mathrm{HCl}$ çözeltisinde hazırlanan) ilave edilerek vortekslenmiştir. Tüpler 35 dak süreyle $100^{\circ} \mathrm{C}$ 'deki su banyosunda renk gelişimi için inkübe edilmiş ve süre sonunda buz banyosunda hızla soğutulmuştur. Örneklerin absorbans 532 nm'de şahit örneğe $(5 \mathrm{ml}$ saf su ve $5 \mathrm{ml} \mathrm{2-}$ tiyobarbitürik asit çözeltisi) karş1 spektrofotometrik olarak belirlenmiş ve TBARM sayısı 1,1,3,3-Tetraetoksipropan ayırac1 kullanılarak çizilen kurve yardımı ile $\mathrm{mg}$ malondialdehyde (MA) $/ \mathrm{kg}$ et olarak hesaplanmıştur.

\section{Hekzanal analizi}

Yaklaşı 3 g homojen nugget örneği 20 ml'lik vial içerisine tartılmış ve GC-MS sisteminin 1sıtıcı bölmesine yerleştirilerek $40^{\circ} \mathrm{C}$ 'de 10 dak süreyle örnek sıcaklığının dengelenmesi için bekletilmiştir. Katı faz ekstraksiyonu için karboksen/ polidimetilsiloksan fiber (CAR/PDMS, $85 \mu \mathrm{m}$ ) viale daldırılarak $40^{\circ} \mathrm{C}$ 'de 40 dak süreyle uçucu bileşenlerin absorbsiyonu sağlanmıştır. Sonraki aşamada fiber bileşenlerin desorpsiyonu için 
sistemin enjeksiyon portunda $250^{\circ} \mathrm{C}$ 'de 10 dak süreyle bekletilmiştir. Hekzanal analizinde gaz kromatografi cihazı (Agilent, 7890 serisi, Agilent Technologies, Santa Clara, CA, USA) ile entegre kütle dedektörü (MS, Agilent, $5975 \mathrm{~N}$ model) ve DB-624 kapiler kolon (Agilent, $30 \mathrm{~m}$ uzunluğunda; $0.25 \mathrm{~mm}$ iç çapında; $1.4 \mu \mathrm{m}$ film kalınlığında) kullanılmıştır. Taşıyıcı gaz $1 \mathrm{ml} / \mathrm{dak}$ akış hızında helyum gazı olup enjeksiyon bloğu sicaklığ $250^{\circ} \mathrm{C}$, dedektör sicakllğ $250^{\circ} \mathrm{C}$, MS kaynağının sicaklığ $230^{\circ} \mathrm{C}$, MS kuadropol sicaklığı $150^{\circ} \mathrm{C}$, elektron enerjisi $70 \mathrm{eV}$ ve kütle aralı̆g 41 400 atomik kütle ünitesi olarak ayarlanmıştır. Başlangiç firın sıcaklığ $40^{\circ} \mathrm{C}$ olup bu sıcaklikta 5 dak tutulduktan sonra sicakllk dakikada $3^{\circ} \mathrm{C}$ artacak şekilde $40^{\circ} \mathrm{C}^{\prime}$ den $110^{\circ} \mathrm{C}$ 'ye; dakikada $4^{\circ} \mathrm{C}$ artacak şekilde $110^{\circ} \mathrm{C}^{\prime}$ den $150^{\circ} \mathrm{C}^{\prime} \mathrm{ye}$; dakikada $10^{\circ} \mathrm{C}$ artacak şekilde $150^{\circ} \mathrm{C}^{\prime}$ den $210^{\circ} \mathrm{C}^{\prime}$ ye çıkarılmış ve $210^{\circ} \mathrm{C}$ 'de 12 dakika tutulmuştur. Hekzanal bileşiği, kütle spektrumu ve alıkonma süresine göre hem standart madde hem de Nist05 (National Institute of Standards and Technology, Gaithersburg MD, USA) and Wiley7.0 (Wiley, NY, USA) kütüphaneleri ile kiyaslama yapılarak tanımlanmıştır. Sonuçlar "pik alanı x 10" olarak verilmiştir (Köroğlu, 2017).

\section{İstatistik analiz}

Analiz sonuçları, tesadüf blokları faktöriyel deneme deseninde tekrarlanan ölçümler düzenine göre SPSS 15 istatistik paket program 1 kullanılarak incelenmiştir. Deneme deseninde tekerrür blok, depolama süresi $(0,1,2,3,4,5,6$ ay) tekrarlanan faktör, gruplar ise (GSS1, GSS2 ve GSS3) sabit faktör olarak düşünülmüştür. İncelenen parametre açısından faktörlerin etkisi anlamlı bulunduğu durumlarda uygulamalar arasındaki farklılığın önemlilik düzeyi $(\alpha=0.05)$ Tukey çoklu karşılaşurma testi kullanılarak belirlenmiştir. Sonuçlar ortalama \pm standart hata olarak verilmiştir.

\section{SONUÇ VE TARTIŞMA}

Sıvı sos bileşiminde farklı oranda pirinç unu, mısır unu ve misır nişastası kullanılarak üretilen glutensiz piliç nuggetların gluten miktarı ve besinsel bileşimine ait sonuçlar Çizelge 2'de verilmiştir. Yapılan analiz sonucunda GSS1, GSS2 ve GSS3 örneklerinin gluten içeriği $<5 \mathrm{mg} / \mathrm{kg}$ olarak bulunmuştur. Kodeks Alimentarus gluten intolerans1 olan bireylere uygun gidalara ilişkin standartta glutensiz gidaların maksimum 20 $\mathrm{mg} / \mathrm{kg}$, gluteni azaltılmış gıdaların ise maksimum $100 \mathrm{mg} / \mathrm{kg}$ gluten içermesine izin verilmektedir (Anonymous, 2008). Bu noktada, çalışma kapsaminda üretilen glutensiz nuggetların uluslararası standarta uygun olduğu ifade edilebilir.

Çizelge 2.Glutensiz piliç nuggetlann nem, protein, yağ, kül ve gluten miktarları Table 2. Moisture, protein, fat, ash, and gluten amounts of gluten-free chicken nuggets

\begin{tabular}{|c|c|c|c|c|c|c|}
\hline & \multicolumn{2}{|c|}{ GSS1* } & \multicolumn{2}{|c|}{ GSS2 } & \multicolumn{2}{|c|}{ GSS3 } \\
\hline & $0 . a y$ & 6.ay & $0 . a y$ & 6.ay & $0 . a y$ & 6.ay \\
\hline & $M O^{\#}$ & $M \sigma^{\#}$ & MO & M6 & MO & M6 \\
\hline $\begin{array}{l}\text { Nem (\%) } \\
\text { Moisture (\%) }\end{array}$ & $59.75 \pm 1.45$ & $58.92 \pm 1.11$ & $60.70 \pm 1.39$ & $59.12 \pm 0.95$ & $60.73 \pm 1.22$ & $59.93 \pm 1.27$ \\
\hline Protein (\%) & $14.76 \pm 0.32$ & $15.04 \pm 0.16$ & $14.80 \pm 0.68$ & $14.63 \pm 0.47$ & $14.85 \pm 0.55$ & $15.03 \pm 0.36$ \\
\hline $\begin{array}{l}\text { Protein (\%) } \\
\text { Yağ (\%) }\end{array}$ & & & & & & \\
\hline Fat $(\%)$ & $9.07 \pm 0.03$ & $9.04 \pm 0.01$ & $9.20 \pm 0.06$ & $9.20 \pm 0.04$ & $9.16 \pm 0.05$ & $9.14 \pm 0.06$ \\
\hline $\begin{array}{l}\text { Kül }(\%) \\
\text { Ash (\%) }\end{array}$ & $1.37 \pm 0.01$ & $1.39 \pm 0.02$ & $1.38 \pm 0.01$ & $1.36 \pm 0.06$ & $1.37 \pm 0.01$ & $1.38 \pm 0.02$ \\
\hline $\begin{array}{l}\text { Gluten }(\mathrm{mg} / \mathrm{kg}) \\
\text { Gluten }(\mathrm{mg} / \mathrm{kg})\end{array}$ & $<5$ & & $<5$ & & $<5$ & \\
\hline
\end{tabular}

*GSS:Glutensiz siv1 sos / Gluten-free batter

GSS1:\%30Pirinç unu/\%70Mısır unu/\%15Mısır nişastas1; GSS2:\%40Pirinç unu/\%60Mısır unu/\% $\%$ Misır nişastası; GSS3:\%40Pirinç unu/\%60Misır unu/\%15Mısır nişastası

GSS1:30\%Rice flour /70\%Corn flour/15\%Corn starch; GSS2:40\%Rice flour/60\%Corn flour/5\%Corn starch; GSS3:40\%Rice flour $60 \%$ Corn flour $/ 15 \%$ Corn starch

\#M0:Zero month, M6:Sixth month 
Farklı bileşimde glutensiz sıvı sos ile hazırlanan nuggetların nem, protein, yağ ve kül değerlerinde depolama süresince istatistik olarak anlamlı bir fark bulunmamıştır ( $P>0.05)$. GSS1, GSS2 ve GSS3 ömeklerinin nem değerleri başlangıçta $\% 59.75-\% 60.73$ aralı̆̆ında iken, depolamanın sonunda $\% 58.92-\% 59.93 \quad$ aralı̆̆ındadır. Depolamanın başında \%14.76-\%14.85 aralığında hesaplanan protein değerleri, 6. ayda \%14.63$\% 15.03$ olarak belirlenmiştir. GSS1, GSS2 ve GSS3 örneklerinin yağ miktarları 0 . ve 6 . ayda sirasiyla $\% 9.07-9.20$ ve $\% 9.04-\% 9.20$ araliklarında bulunmuştur. Örneklerin kül miktarları ise depolamanın başında \%1.37-\%1.38 olarak belirlenirken, 6. ayda \%1.36-\%1.39 aralığında hesaplanmıştır. Benzer şekilde Gökçe vd. (2016), buğday, misır, soya ve çavdar gibi farklı unların kaplamada kullanımının nuggetların nem ve yağ içeriği üzerine etkili olmadığını vurgulamıştır. Nugget kaplamasinda \%10 ve \%20 oraninda yulaf unu kullanımının ise karbonhidrat içeriğindeki artışa bağlı olarak daha düşük yağ ve protein miktarıyla sonuçlandığı tespit edilmiştir (Santhi ve Kalaikannan, 2014).

Jackson vd. (2006) tarafından yapılan çalışmada sıvı sos bileşiminde $\% 42.75$ oranında pirinç unu kullanılan nuggetların nem, protein ve yağ değerleri sirasiyla $\% 58.50, \% 20.13$ ve $\% 5.23$ olarak rapor edilmiştir. Bu sonuçlar, Çizelge 2'de verilen nem değerleri ile benzerlik gösterirken, pirinç ve mısır unu karışımı kullanılarak tarafimızca yapılan çalışmada daha düşük protein ve daha yüksek yağ miktarları tespit edilmiştir. Bu sonucun, Jackson vd. (2006) tarafindan yapilan çalışmada sıvı sos bileşiminde \%13 oranında yumurta ve $\% 91$ oranında gögüs eti kullanımı ile tarafımızca yapılan çalışmada kuru sos bileşiminde \%2-5 oranında ayçiçek yağı kullanımına bağlı olduğu düşünülmektedir. Missbach vd. (2015) tarafından yapılan çalışmada, Avusturya'da 3 farklı marketten toplanan glutensiz nuggetlann protein ve yağ içerikleri sırasıyla ortalama $\% 15.3$ ve $\% 11.0$ olarak bulunmuş olup çalışmamızdaki sonuçlar ile benzerlik göstermektedir. Bir diğer çalışmada, pirinç ve misır unu $(40: 60 \mathrm{w} / \mathrm{w})$ kullanılarak formüle edilen kaplamaların nem ve yağ değerleri sirasiyla $\% 56.85-\% 58.82$ ve $\% 9.20-\% 10.48$ aralığında belirlenmiş olup çalışmamızda elde edilen veriler ile uyumludur (Mukprasirt vd., 2001). Soncu (2014) tarafindan yürütülen piyasa çalışmasında ise, ayak üstü restoranlarından temin edilen buğday unu kaynaklı piliç nuggetlarda \%38.37-\%57.79 aralığında nem, \%14.94-\%18.75 aralığında protein, $\% 13.16-\% 22.60$ aralığında yă̆ ve \%2.01-2.59 aralığında kül içeriği belirlenmiştir. Ticari koşullarda buğday unu kullanılarak üretilen nuggetlar ile glutensiz nuggetlar kıyaslandığında, glutensiz nuggetların daha düşük yağ ve kül içeriğine sahip olduğu, ticari nuggetlara kiyasla protein açısından alt limitlerde, nem açısından da üst limitlerde sonuçlar elde edildiği gözlenmiştir. Bir diğer buğday unu kaynaklı nugget üretim çalışmasında da ürünlerin nem, yağ, protein ve kül içerikleri sırasıyla $\% 53.55, \% 13.43, \% 16.01$ ve \%2.43 olarak tespit edilmiştir (Akoğlu, 2012). Çalışmamızda, glutensiz piliç nuggetlarda belirlenen yüksek nem ve düşük yağ içeriğinin sıvı sos bileşiminde $\% 2$ düzeyinde karboksimetil selüloz (KMS) kullanımı ve üretim prosesinde derin yağda kızartma yerine buharlı firında pişirme uygulanması ile ilişskili olduğu düşünülmektdir. Çünkü derin yağda kızartma sırasında, viskoelastik yapiya sahip buğday ununun kabarma etkisinin bir sonucu olarak buğday unu kaynaklı kaplamalarda oluşan porlar yağın absorpsiyonunu suyun ise evaporasyonunu kolaylaştırarak nem içeriğinde azalışa yağ içeriğinde de artşa neden olur (Shih ve Daigle, 1999; Mukprasirt vd., 2001; Tașbaș vd., 2016). KMS ise hidrofilik yapis1 sayesinde 1 sil işlem sırasinda termal jelleşmenin bir sonucu olarak yüksek viskoziteli bir kaplama oluşturarak nem ve yağ transferi için belirli düzeyde bariyer görevi görür (Mukprasirt vd., 2001; Haghshenas vd., 2015). Ayrıca pirinç ve mısır unu kullanılarak üretilen nuggetların buğday unu kaynaklı nuggetlara göre daha düşük yağ içeriğine sahip oluşu, pirincin buğdaya kiyasla daha yüksek oranda amiloz içermesi nedeniyle yağ bağlama kapasitesinin daha düşük oluşu ile ilişkilendirilebilir (Shih ve Daigle, 1999).

SYA miktarındaki değişim depolama koşullarında lipitlerin stabilitesi hakkinda fikir veren bir parametredir (Das vd., 2008). Farklı bileşimdeki glutensiz sıv1 sos ile üretilen nuggetların SYA değerleri Çizelge 3'de verilmiştir. Depolama süresi boyunca örneklerin SYA miktarlarında değişim 
gözlenmiştir. Başlangıçta GSS1, GSS2 ve GSS3 örnekleri için sırasiyla $\% 0.91, \% 0.82$ ve $\% 0.88$ olarak belirlenen SYA değerleri 6. ayında sonunda istatistik olarak önemli düzeyde artıs göstererek sirastyla \%1.23, \%1.21 ve \%1.20 değerlerine ulaşmışıı $(P<0.05)$. Farklı bileşimdeki sıvı soslar kullanılarak üretilen glutensiz nuggetlar arasında ise fark bulunamamıstır $(P>0.05)$. Benzer bir çalışmada, nugget kaplamasında yeşil muz kabuğu unu $(\% 4)$ ve soya kabuğu ununun $(\% 4)$ tek başına ya da birlikte kullanımının $4^{\circ} \mathrm{C}$ 'de 25 gün süreyle depolanan nuggetların SYA değerleri üzerine etkili olmadığı ancak SYA değerinin depolama süresince artış gösterdiği bildirilmiştir (Kumar vd., 2013). Özetle, yapılan çalışmalar, hidroliz reaksiyonlarının göstergesi olan SYA miktarının depolama süresi ile ilişkili olduğunu, süre arttıkça SYA değerinin de arttı̆ını göstermiştir (Modi vd., 2004; Das vd., 2008; Chandralekha vd., 2012; Reddy, 2017).

Çizelge 3. Glutensiz piliç nuggetların donmuş depolama sürecinde SYA, konjuge dien ve konjuge trien değerlerindeki değişim

Table 3.Changes in FFA, conjugated dien and conjugated trien values of gluten-free chicken nuggets during frozen storage

\begin{tabular}{|c|c|c|c|c|}
\hline & & GSS1* & GSS2 & GSS3 \\
\hline \multirow{7}{*}{ 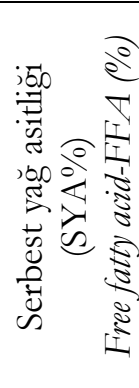 } & 0.ay / $M 0^{\#}$ & $0.91 \mathrm{~b} \pm 0.04$ & $0.82^{\mathrm{b}} \pm 0.06$ & $0.88^{\mathrm{b}} \pm 0.08$ \\
\hline & 1.ay / M1\# & $1.30^{a} \pm 0.10$ & $1.17 \mathrm{ab} \pm 0.02$ & $1.31^{\mathrm{a}} \pm 0.06$ \\
\hline & 2.ay / M2\# & $1.12^{\mathrm{ab} \pm 0.09}$ & $1.14 \mathrm{ab} \pm 0.08$ & $1.16^{\mathrm{ab} \pm 0.09}$ \\
\hline & 3.ay / M3\# & $1.26^{\mathrm{ab}} \pm 0.11$ & $1.26 \mathrm{a} \pm 0.09$ & $1.18 \mathrm{ab} \pm 0.08$ \\
\hline & 4.ay / $M 4^{\#}$ & $1.32^{\mathrm{a}} \pm 0.10$ & $1.24^{a} \pm 0.09$ & $1.24 \mathrm{ab} \pm 0.04$ \\
\hline & 5.ay / M5\# & $1.30^{a} \pm 0.06$ & $1.28^{a} \pm 0.12$ & $1.28 \mathrm{a} \pm 0.04$ \\
\hline & 6.ay / $M \sigma^{\#}$ & $1.23 \mathrm{ab} \pm 0.10$ & $1.21 \mathrm{a} \pm 0.09$ & $1.20^{\mathrm{ab}} 0.15$ \\
\hline \multirow{7}{*}{ 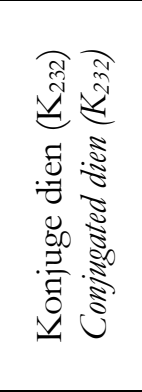 } & 0.ay / MO & $4.79 a \pm 0.28$ & $6.27 a \pm 1.20$ & $4.57 a \pm 0.40$ \\
\hline & 1.ay / M1 & $4.67 a \pm 0.57$ & $4.84 \mathrm{ab} \pm 0.78$ & 4.81a \pm 0.64 \\
\hline & 2.ay / M2 & $3.92^{\mathrm{a}} \pm 1.55$ & $4.08^{\mathrm{b}} \pm 0.75$ & $4.36^{a} \pm 0.93$ \\
\hline & 3.ay / M3 & $3.93^{\mathrm{a}} \pm 0.34$ & $3.58^{\mathrm{b}} \pm 0.16$ & $3.31^{\mathrm{a}} \pm 0.15$ \\
\hline & 4.ay / M4 & $4.16^{a} \pm 0.10$ & $4.18^{b} \pm 0.34$ & $4.18 \mathrm{a} \pm 0.43$ \\
\hline & 5.ay / M5 & $2.95^{a} \pm 0.26$ & $3.86^{\mathrm{b}} \pm 0.66$ & $3.65^{a} \pm 0.40$ \\
\hline & 6.ay / M6 & $3.55^{a} \pm 0.37$ & $3.93^{b} \pm 0.58$ & $3.79 a \pm 0.65$ \\
\hline \multirow{7}{*}{ 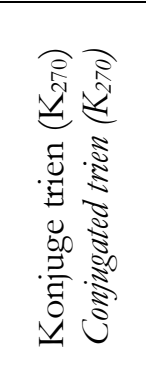 } & 0.ay / MO & $1.60^{a} \pm 0.06$ & $1.93 a \pm 0.21$ & $1.56^{a} \pm 0.25$ \\
\hline & 1.ay / M1 & $1.44 a \pm 0.07$ & $1.49 \mathrm{ab} \pm 0.21$ & $1.42^{a} \pm 0.14$ \\
\hline & 2.ay / M2 & $1.27 \mathrm{a} \pm 0.48$ & $1.24 \mathrm{ab} \pm 0.12$ & $1.33^{a} \pm 0.18$ \\
\hline & 3.ay / M3 & $1.30^{a} \pm 0.11$ & $1.16^{\mathrm{b}} \pm 0.06$ & $1.09^{\mathrm{a}} \pm 0.12$ \\
\hline & 4.ay / M4 & $1.35^{a} \pm 0.11$ & $1.42^{\mathrm{ab}} \pm 0.07$ & $1.45^{\mathrm{a}} \pm 0.05$ \\
\hline & 5.ay / M5 & $1.01 \mathrm{a} \pm 0.05$ & $1.23 \mathrm{ab} \pm 0.20$ & $1.23^{\mathrm{a}} \pm 0.10$ \\
\hline & 6.ay / M6 & $1.19 \mathrm{a} \pm 0.03$ & $1.30^{\mathrm{ab}} \pm 0.09$ & $1.27 \mathrm{a} \pm 0.13$ \\
\hline
\end{tabular}

a,b:Farklı harfleri taşıyan aynı sütundaki ortalamalar arasındaki fark istatistik olarak önemlidir $(P<0.05)$

a,b:The difference between means with different letters in the same column are statistically significant $(P<0.05)$

*GSS:Glutensiz siv1 sos / Gluten-free batter

GSS1:\%30Pirinç unu/\%70Misır unu/\%15Misır nişastas1; GSS2:\%40Pirinç unu/\%60Misır unu/\%5Mısır nişastas1; GSS3:\%40Pirinç unu/\%60Misır unu/\%15Misır nişastası

GSS1:30\%Rice flour $70 \%$ Corn flour/15\%Corn starch; GSS2:40\%Rice flour/60\%Corn flour/5\%Corn starch; GSS3:40\%Rice flour $60 \%$ Corn flour $15 \%$ Corn starch

\#M0:Zero month, M1:First month, M2:Second month, M3:Third month, M4:Fourth month, M5:Fifth month, M6:Sixth month 
Lipit oksidasyonunun başlangıç aşamasında lipitlerin parçalanması sonucu açığa çıan dien konjuge linoleik hidroperoksit bileşikleri spesifik dalga boyunda $(232 \mathrm{~nm})$ tanımlanabilirler (Serim, 1991; Cagdas ve Kumcuoglu, 2015). Konjuge dien bileşiklerinin miktarının birincil oksidasyon ürünlerinden biri olan hidroperoksit oluşumu ile paralel bir şekilde arttığ (Dominguez vd., 2019) ve hidroperoksitlerin ikincil oksidasyon ürünlerine dönüşmesi ile birlikte konjuge dien bileşiklerinin miktarının da azaldığı bilinmektedir. Ayrıca konjuge dien bileşiklerinin miktarındaki bu azalış TBARM sayısındaki artşsı da işaret etmektedir (Cagdas ve Kumcuoglu, 2015). Çizelge 3 'te verilen konjuge dien ve konjuge trien değerleri incelendiğinde, GSS1 ve GSS3 örnekleri için depolama süresinin sonunda azalış tespit edilmesine rağmen bu değişim istatistik olarak anlamlı değildir $(P>0.05)$. GSS2 örneğinde ise başlangiçta 6.27 olarak belirlenen konjuge dien değeri depolamanın sonunda azalarak 6. ayda 3.93 değerine ulaşmıştır $(P<0.05)$. Konjuge trien ise $270 \mathrm{~nm}$ dalga boyunda absorplanan trien konjuge linolenik hidroperoksit bileşikleri ve bunlardan oluşan ketonlar olarak bilinir (Serim, 1991). Benzer şekilde konjuge trien değeri de depolama süresince azalış eğilimi göstermiştir. GSS2 örneğinde 0 . ayda 1.93 olarak hesaplanan konjuge trien değeri depolamanın sonunda 1.30 olarak bulunmuştur $(P<0.05)$. Konjuge dien ve trien bileşiklerindeki bu azalışın lipit oksidasyonunun ilerlemesi ve ikincil oksidasyon bileşiklerinin oluşumu ile ilişskili olduğu düşünülmüştür. Yapılan bir çalışmada, 5 ay süreyle $-18^{\circ} \mathrm{C}$ 'de depolanan piliç nuggetlarda da depolamanın 2. ayında artarak en yüksek değerine ulaşan konjuge dien değeri sonrasında azalış göstermiştir (Cagdas ve Kumcuoglu, 2015). Kitre ya da karragenan kullanılarak enkapsüle edilmiş balık yağı ile zenginleştirilmiş nuggetlarda ise $-18^{\circ} \mathrm{C}$ 'de 3 ay süreyle depolama aşamasında konjuge dien değerleri birinci ayın (30. gün) sonunda artış gösterirken konjuge dien bileşiklerinin parçalanmasına bağlı olarak depolamanın son gününde (90. gün) başlangıç (0. gün) değerlerine yakın sonuçlar elde edilmiştir (Pourashouri vd., 2020). Çalışmamızda depolamanın 0. ve 6. ayı kıyaslandığında konjuge dien ve trien değerlerinde azalış belirlenmiş olsa da, sonuçlar ay bazında incelendiğinde yapılan çalışmalara benzer şekilde bu değerlerde 4. ayda artış, 5. ayda azalış ve 6. ayda tekrar artış söz konusudur. Bu sonuç, birincil oksidasyon ürünlerinin ikincil oksidasyon ürünlerine dönüşürken aynı zamanda halen birincil oksidasyon ürünlerinin oluşmaya devam ettiğini de göstermektedir.

TBARM sayıs1 et ve et ürünlerinde lipit oksidasyon düzeyinin belirlenmesi için kullanılan (Amaral vd., 2018; Feridoni ve Shurmasti, 2020), aldehitler, karboniller ve hidrokarbonlar gibi ikincil oksidasyon ürünlerinin miktarı hakkında bilgi veren bir yöntemdir (Cagdas ve Kumcuoglu, 2015). Glutensiz nuggetlara ilişkin TBARM değerleri Şekil 1'de verilmiştir. Depolama başlang1cinda GSS1, GSS2 ve GSS3 örnekleri için sirasiyla $0.18,0.16$ ve $0.08 \mathrm{mg} \mathrm{MA} / \mathrm{kg}$ olarak belirlenen TBARM değerleri, 6. ayda sirasiyla $0.33,0.38$ ve $0.34 \mathrm{mg} \mathrm{MA} / \mathrm{kg}$ değerlerine ulaşmıştır $(P<0.05)$. Aylar arasındaki değişim incelendiğinde ise GSS1 ve GSS2 örneklerinin TBARM sayllarında ilk 2 ayda düşüş tespit edilmişir. Bu sonuç TBA testi için beklenen bir durum olup, oksidasyon sırasında açığa çıkan kısa karbon zincirli oksidasyon ürünlerinin organik alkol ve asitlere parçalanması veya ikincil oksidasyon ürünlerinden olan malondialdehitin amino asitler ile reaksiyona girmesi TBARM sayısındaki düşüşü açıklamaktadır (Mukprasirt vd., 2001). Bu düşüşü takiben özellikle 2. ay ile k1yaslandığında 3.ayda TBARM sayılarında GSS1 örneğinde \%87, GSS2 için \%85 ve GSS3 örneğinde ise $\% 100$ düzeyinde hesaplanan artş dikkat çekicidir $(P<0.05)$.

Lipit oksidasyonu üzerine etkili faktörlerden biri depolama süresi ve sıcaklığıdır. Et sektöründe donmuş depolama oksidatif reaksiyonları durdurmak amaciyla kullanilsa da tamamen engellenmesi mümkün değildir. Çünkü et ve et ürünlerinin dondurulması aşamasında su sıv1 fazdan katı faza geçerken hacimdeki artışa bağlı olarak hücre çeperi parçalanır ve hücre içi enzimler serbest hale gelir. Ayrica $-18^{\circ} \mathrm{C}$ de halen sıvı fazda bulunan az miktardaki su ile hücre içi ve hücre dış1 enzimler donmuş depolama sürecinde lipoliz reaksiyonların ve birincil oksidasyon ürünlerinin oluşumunu tetikler (Leygonie vd., 
2012; Utrera vd., 2014). Çözündürme aşamasında ise koşullara bağlı olarak birincil oksidasyon ürünleri ikincil oksidasyon ürünlerine dönüşür (Leygonie vd., 2012; Dominguez vd., 2019). Depolama süresindeki artışı ise serbest radikal oluşumunu tetiklediği, uzun depolama koşullarında heme-protein yapısından ayrilarak serbest kalan demirin lipit oksidasyonunun başlangiç ve gelişme aşamalarındaki birçok reaksiyonu katalizlediği bilinmektedir (Dominguez vd., 2019). Bu açıklamalar, $-18^{\circ} \mathrm{C}$ 'de 6 ay süreyle depolanan glutensiz nuggetlarda lipit oksidasyonuna bağlı TBARM sayısındaki artışı desteklemektedir. Benzer şekilde, pirinç ve misır unu içeren kaplama ile kaplanmış ve 3 ay süreyle $18^{\circ} \mathrm{C}$ 'de depolanan piliç butlanı TBARM değeri depolama süresince artış göstermiştir (Mukprasirt vd., 2001). Bir diğer çalışmada glutensiz buğday unu kullanılarak üretilen ve 21 gün süreyle $4^{\circ} \mathrm{C}^{\prime} \mathrm{de}$ depolanan nuggetlarda da TBARM sayisinda artan depolama süresi ile birlikte artış tespit edilmiştir (Tașbaș vd., 2016). Amarant ununun \%50 ve $\% 100$ oranında buğday unu yerine kullanıldığ1 çalışmada da (Tamsen vd., 2018), $4^{\circ} \mathrm{C}$ 'de 13 gün süreyle depolanan glutensiz nuggetlarda lipit oksidasyonunun bir sonucu olarak TBARM değerinin yükseldiği belirlenmiştir. Literatürde çok sayıda benzer çalışmaya rastlamak mümkün olup bu çalışmaların ortak çıktısı, $4^{\circ} \mathrm{C}$ 'de ya da $18^{\circ} \mathrm{C}$ 'de depolanan piliç nuggetlarda TBARM sayının depolama süresince artış göstermesidir (Kumar vd., 2013; Cagdas ve Kumcuoglu, 2015; Haghshenas vd., 2015; Sohaib vd., 2017; Feridoni ve Shurmasti, 2020).

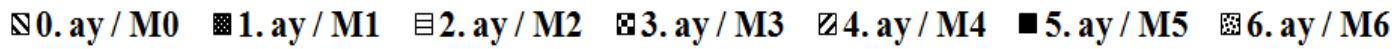

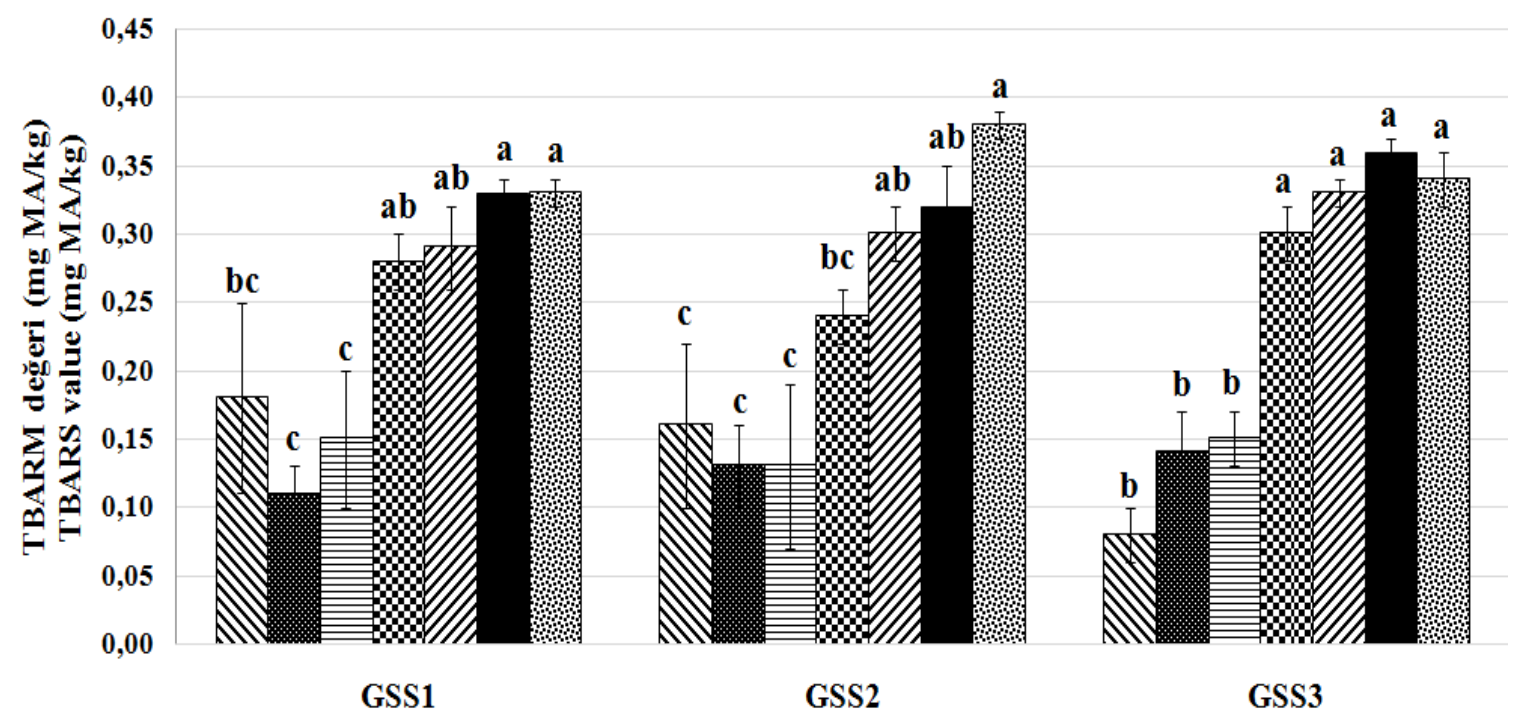

a,b,c:Aynı grupta farklı harfleri taşıyan ortalamalar arasındaki fark istatistik olarak önemlidir $(P<0.05)$

$a, b, c:$ The difference between means with different letters in the same group are statistically significant $(P<0.05)$

GSS:Glutensiz siv1 sos / Gluten-free batter

GSS1:\%30Pirinç unu/\%70Misır unu/\%15Misır nişastas1; GSS2:\%40Pirinç unu/\%60Misır unu/\%5Misır nişastası; GSS3:\%40Pirinç unu/\%60Misır unu/\%15Misır nişastas1

GSS1:30\%Rice flour / 70\% Corn flour/ 15\% Corn starch; GSS2:40\%Rice flour $/ 60 \%$ Corn flour/ 5\% Corn starch; GSS3:40\%Rice flour $60 \%$ Corn flour $15 \%$ Corn starch

M0:Zero month, M1:First month, M2:Second month, M3:Third month, M4:Fourth month, M5:Fifth month, M6:Sixth month

TBARM:Tiyobarbitürik asit reaktif madde sayıs1 /TBARS:Thiobarbituric acid reactive substance value

Şekil 1. Glutensiz piliç nuggetların depolama sürecince TBARM değerlerindekideğişim Figure 1. Changes in TBARS value of gluten-free chicken nuggets during frozen storage 
Şekil 1'deki veriler farklı sıv1 sos bileşiminin etkisi açısından incelendiğinde ise farklı oranlarda pirinç unu, mısır unu ve mısır nişastası kullanımının TBARM sayısı üzerine etkili olmadığ sonucuna varılmıştır $(P$ >0.05). Yağ miktarının lipit oksidasyonu üzerine etkili olduğu bilinmekle birlikte (Mukprasirt vd., 2001), GSS1, GSS2 ve GSS3 örneklerinin benzer yă̆ miktarnna sahip oluşu, TBARM sayıları arasında bir fark bulunmamasını destekler niteliktedir. Benzer şekilde Jackson vd. (2009) tarafindan yapilan çalışmada da, kaplama bileşiminde pirinç ya da buğday unu kullanımının $-23^{\circ} \mathrm{C}$ 'de 90 gün süreyle depolanan nuggetların TBARM sayisı üzerine etkili olmadığı belirlenmiștir. Bir ürünün tüketiciler tarafindan kabul görmesi için sınır TBARM değeri $2 \mathrm{mg}$ MA/kg olarak belirlenmiş olup (Feridoni ve Shurmasti, 2020), 6 aylik donmuş depolama sonunda ölçülen TBARM değerleri bu limitin altında kalmıştır. Bu sonuç, farklı oranda pirinç unu, misır unu ve misır nişastası kullanılarak üretilen glutensiz nuggetların 6 ay süreyle güvenle tüketilebileceğini göstermiştir.

Pişmiş et ürünlerinde, ikincil oksidasyon ürünleri olan hekzanal, pentanal, 2,4-decadienal, 2,3octanedione ve 2-octenal gibi uçucu karbonil bileşiklerinin oluşumu lipit oksidasyonu ile ilişkilendirilmektedir (Cagdas ve Kumcuoglu, 2015). Bu bileşikler içerisinden özellikle hekzanal miktarının belirlenmesi, et ve et ürünlerinde lipit oksidasyon düzeyinin belirlenmesi açısından önemli bir indikatör olarak görülmektedir (Ross ve Smith, 2006; Guyon vd., 2016; Dominguez vd., 2019). Çünkü hekzanal miktarındaki artıs diğer aldehitlere kiyasla daha yüksek olmakla birlikte hekzanal özellikle n-6 doymamış yağ asitlerince zengin et ve et ürünlerinde lipit oksidasyonunun bir göstergesidir (Ross ve Smith, 2006; Dominguez vd., 2019). Çalışmamızda, hekzanal verilerine ilişkin istatistik olarak anlamlı bir fark bulunamamiştur $(P>0.05)$. Şekil 2'de verilen sonuçlar incelendiğinde, 6 aylık donmuş depolama süresince artış ve azalışların belirlendiği, en yüksek hekzanal değerine ise GSS1 (40.64 pik alan1 x 106) ve GSS3 (42.29 pik alanı x 106) için 1. ayda, GSS2 için ise 2. ayda (40.59 pik alanı x 106) ulaşıldığ1 gözlenmiştir. Bu pik seviyesinden sonra ilerleyen aylarda azalan hekzanal miktarı depolamanın son aylarında tekrar artış göstermiştir. Ayrıca 0. ve 6. aylara ait hekzanal değerleri kıyaslandığında da depolamanın sonunda GSS1 ve GSS3 örneklerinde sirasiyla $\% 56$ ve $\% 22$ düzeyinde artış gözlenirken, GSS2 örneğinde yaklaşı \%10'luk bir azalış hesaplanmıştır. Hekzanal miktarındaki azalışlar, hekzanal bileşiğinin proteinlerin serbest amino ($\mathrm{NH}_{2}$ ) ya da sülfidril $(-S H)$ gruplarına bağlanması sonucu uçuculuğunu yitirmesi ve tespit edilememesi ile ilişkilendirilmektedir (Pignoli vd., 2009). Çalışmamızın sonuçları ile benzer şekilde, soğuk ya da donmuş depolama koşullarında yürütülen çalışmalarda da, lipit oksidasyonunun bir göstergesi olarak piliç etinde hekzanal içeriğinin arttığı ifade edilmiştir (Hassan ve Fan, 2005; Sampaio vd., 2012; Marques Pino vd., 2013; Sohaib vd., 2017).

Özetle bu çalışma verileri, farklı oranda pirinç unu:misir unu (40:60 ya da 30:70) ve misir nişastası ( $\% 5$ ya da $\% 15)$ ile formüle edilen sıvı sos kullanılarak üretilen glutensiz nuggetlarda 6 aylık donmuş depolama periyodunda açığa çıkan lipolitik reaksiyonların düzeyi hakkında detaylı bilgi sunmaktadir. Lipoliz ve lipit oksidasyonu reaksiyonlarının depolama süresince artış eğiliminde olduğu ancak sonuçların güvenli tüketim limitlerini aşmadiğ1 tespit edilmiştir. Ayrıca farklı bileşimde sıvı sos kullanımının bu reaksiyonlar üzerine etkili bir faktör olmadığ $1 \mathrm{da}$ belirlenmiştir. Çalışma sonuçları, 3 farklı sıvı sos formülasyonu kullanılarak üretilen glutensiz nuggetların, donuk olarak satışa sunulduğu takdirde 6 ay süreyle güvenle tüketilebileceğini ve bu süreçte lipolitik değişimler açısından ürün kalitesinin korunduğunu göstermiştir. 


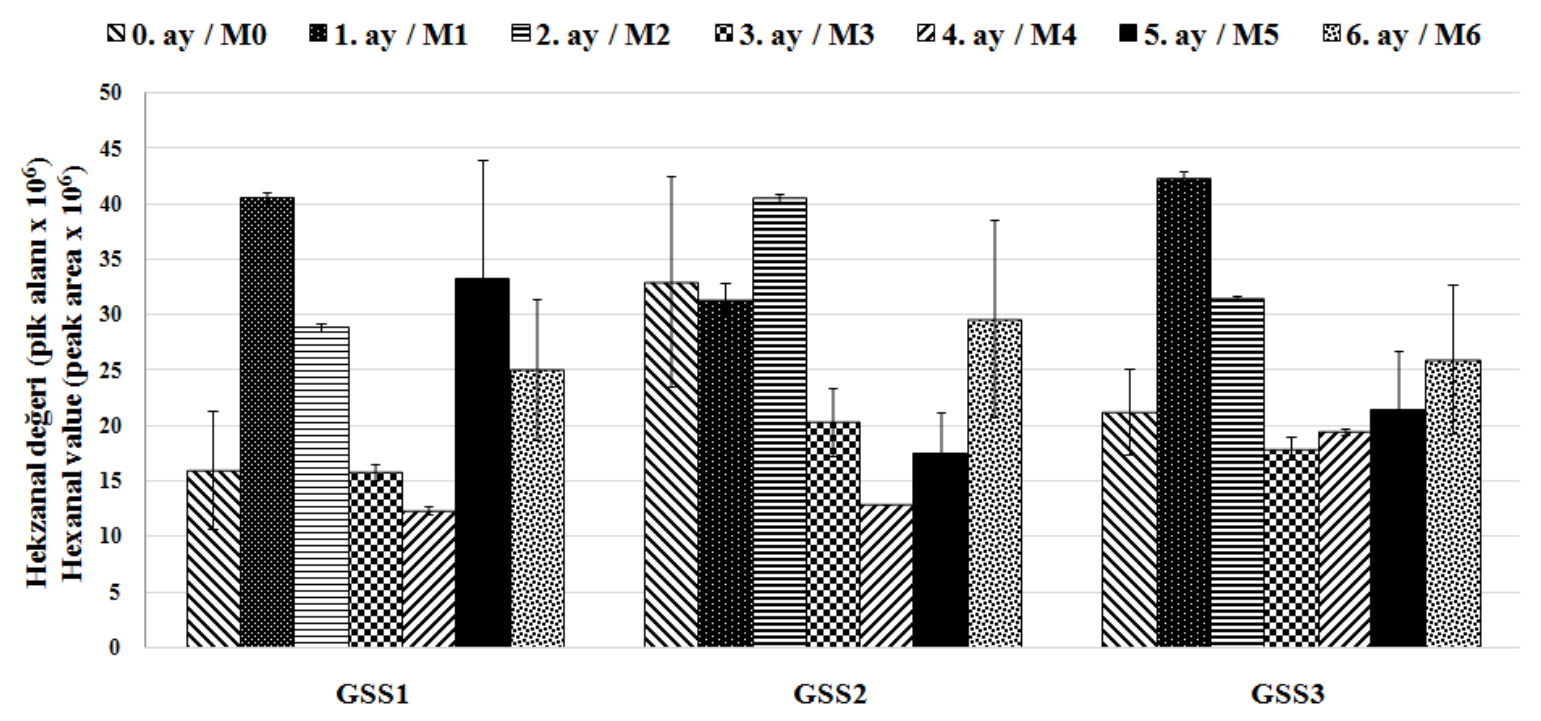

GSS:Glutensiz siv1 sos / Gluten-free batter

GSS1:\%30Pirinç unu/\%70M1sır unu/\%15M1sır nişastas1; GSS2:\%40Pirinç unu/\%60Mısır unu/\%5Mısır nişastası; GSS3:\%40Pirinç unu/\%60Misır unu/\%15Misır nişastası

GSS1:30\%Rice flour/ 70\% Corn flour/ 15\% Corn starch; GSS2:40\%Rice flour/60\% Corn flour/ 5\% Corn starch; GSS3:40\%Rice flour $160 \%$ Corn flour $15 \%$ Corn starch

M0:Zero month, M1:First month, M2:Second month, M3:Third month, M4:Fourth month, M5:Fifth month, M6:Sixth month

Şekil 2. Glutensiz piliç nuggetların depolama sürecinde hekzanal değerlerindeki değişim

Figure 2. Changes in hexanal value of gluten-free chicken nuggets during frozen storage

\section{ÇIKAR ÇATIŞMASI}

Yazarlar tarafindan bildirilen herhangi bir çıar çatışması yoktur.

\section{YAZARLARIN KATKISI}

Esra Selin DAVARCIOĞLU, nugget hamuru ile sıvı ve kuru sos formülasyonlarının geliştirilmesi, denemenin kurulması, besinsel bileşim ve TBARM analizlerinin yapilması, istatistik değerlendirme aşamalarında, Eda DEMIROK SONCU ise denemenin kurulmasi, hekzanal, serbest yağ asitliği, konjuge dien ve konjuge trien analizlerinin yapılması, istatistik değerlendirme ve makalenin yazım sürecinde görev almıştır.

\section{TEŞEKKÜR}

$\mathrm{Bu}$ çalışma Ankara Üniversitesi Bilimsel Araştırma Projeleri Koordinatörlüğü tarafından desteklenen "15L0443009" nolu ve "Glutensiz tavuk nugget üretiminde alternatif ürün formülasyonları, kalite karakteristikleri ve depolama stabilitesindeki değişimler" konulu projeden yola çıkılarak hazırlanmıştır. Tüm çalışma boyunca desteğini ve bilgisini bizden esirgemeyen, bize yol gösteren doktora danışmanımız Prof. Dr. Nuray KOLSARICI'ya teşekkürü bir borç biliriz. Ayrıca glutensiz nugget üretimi aşamasında proje ekibine değerli katkısını esirgemeyen Erpiliç Entegre Tavukçuluk Üretim Pazarlama ve Tic. Ltd. Şti Ar-Ge birimi çalışanlarına da teşekkürlerimizi sunuyoruz.

\section{KAYNAKLAR}

Akoğlu, İ.T. (2012). Konjuge linoleik asidin (KLA) mikroenkapsülasyonu ve kaplamalı tavuk eti ürünlerinin KLA ile zenginleştirilmesi. Ankara Üniversitesi Fen Bilimleri Enstitüsü G1da Mühendisliği Anabilim Dalı Doktora Tezi, Ankara, Türkiye, $110 \mathrm{~s}$.

Amaral, A.B., Silva, M.V.d., Lannes, S.C.Ds. (2018). Lipid oxidation in meat: mechanisms and protective factors-a review. Food Sci.Tech., 38: 115.

Anonymous. (2008). Standard for foods for special dietary use for persons intolerant to gluten. 
CXS-118 1979. In: Codex Alimentarus International Food Standards.

Anonymous. (2017). Çölyak ve görülme sıklığı. https://hsgm.saglik.gov.tr/tr/metabolizma-vecolyak/

AOAC. (2010a).Official methods of analysis of $A O A C$ International. Washington, DC, USA.

AOAC. (2010b). Official method 991.19: Gliadin as a measure of gluten in foods: Colorimetric monoclonal antibody enzyme immunoassay method. First action 1991. Final action 2001. In: $A O A C$ International, Gaithersburg, MD.

Bligh, E.G., Dyer, W.J. (1959). A rapid method of total lipid extraction and purification. Can.J. Biochem. Physiol., 37(8): 911-917.

Cagdas, E., Kumcuoglu, S. (2015). Effect of grape seed powder on oxidative stability of precooked chicken nuggets during frozen storage. J. Food Sci. Technol., 52(5): 2918-2925.

Catassi, C., Fasano, A. (2008). Celiac disease. In: Gluten-free cereal products and beverages. Elsevier, pp. $2-28$.

Chandralekha, S., Babu, A.J., Moorthy, P.S., Karthikeyan, B. (2012). Studies on the effect of pomegranate rind powder extract as natural antioxidant in chicken meat balls during refrigerated storage. J. Adv. Vet. Res., 2(2): 107112.

Das, A.K., Anjaneyulu, A., Gadekar, Y., Singh, R.P., Pragati, H. (2008). Effect of full-fat soy paste and textured soy granules on quality and shelf-life of goat meat nuggets in frozen storage. Meat Sci., 80(3): 607-614.

Davarcioglu, E., Kolsarici, N. (2019). Effects of innovative gluten-free coatings on quality, sensory and microbial properties of chicken nuggets.Ital. J. Food Sci., 31(2): 385-400.

de Carvalho, L.R.S., da Silva, C.H.D., Giada, Md.L.R. (2018). Physical, chemical and sensorial properties of low-fat and gluten-free chicken nuggets. J. Culin. Sci. Technol., 16(1): 18-29.

Devatkal, S., Kadam, D., Naik, P., Sahoo, J. (2011). Quality characteristics of gluten-free chicken nuggets extended with sorghum flour. J. Food Qual., 34(2): 88-92.

Dominguez, R., Pateiro, M., Gagaoua, M., Barba, F.J., Zhang, W., Lorenzo, J.M. (2019). A comprehensive review on lipid oxidation in meat and meat products. Antioxidants, 8(10): 429-459.

Feridoni, S.B., Shurmasti, D.K. (2020). Effect of the nanoencapsulated sour tea (Hibiscus sabdariffa L.) extract with carboxymethylcellulose on quality and shelf life of chicken nugget. Food Sci. Nutr., 8(7): 3704-3715.

Gandemer, G. (2002). Lipids in muscles and adipose tissues, changes during processing and sensory properties of meat products. Meat Sci., 62(3): 309-321.

Gökçe, R., Akgün, A.A., Ergezer, H., Akcan, T. (2016). Farklı kaplama bileşenleriyle kaplamanın derin yağda kızartılan piliç nuggetların bazı kalite karakteristikleri üzerine etkileri. Tar. Bil. Der., 22: 331-338.

Guyon, C., Meynier, A., de Lamballerie, M. (2016). Protein and lipid oxidation in meat: A review with emphasis on high-pressure treatments. Trends Food Sci. Technol. 50: 131-143.

Haghshenas, M., Hosseini, H., Nayebzadeh, K., Kakesh, B.S., Mahmoudzadeh, M., Fonood, R.K. (2015). Effect of beta glucan and carboxymethyl cellulose on lipid oxidation and fatty acid composition of pre-cooked shrimp nugget during storage. LWT-Food Sci. Technol. 62(2): 1192-1197.

Hassan, O., Fan, L.S. (2005). The anti-oxidation potential of polyphenol extract from cocoa leaves on mechanically deboned chicken meat (MDCM). LWT-Food Sci. Technol. 38(4): 315-321.

Jackson, V., Schilling, M., Coggins, P., Martin, J.M. (2006). Utilization of rice starch in the formulation of low-fat, wheat-free chicken nuggets. J. Appl. Poult. Res. 15(3): 417-424.

Jackson, V., Schilling, M., Falkenberg, S., Schmidt, T.B., Coggins, P.C., Martin, J.M. (2009). Quality characteristics and storage stability of baked and fried chicken nuggets formulated with wheat and rice flour. J Food Qual., 32(6): 760-774. 
Jnawali, P., Kumar, V. Tanwar, B. (2016). Celiac disease: Overview and considerations for development of gluten-free foods. Food Sci. Hum. Well., 5(4): 169-176.

Kerimoğlu, B.Ö., Serdaroğlu, M. (2019). Celiac disease and new attempts to develop gluten-free meat product formulations. Food and Health 5(4): 253-264.

Kıralan, M. (2010). Türk zeytinyağlarının zeytin çeşitlerine göre aroma profillerinin belirlenmesi. Ankara Üniversitesi Fen Bilimleri Enstitüsü Gida Mühendisliği Anabilim Dalı, Ankara, Türkiye, 159 s.

Köroğlu, E.S. (2017). Glutensiz tavuk nugget üretiminde alternatif ürün formülasyonlari, kalite karakteristikleri ve depolama stabilitesindeki değişimler. Ankara Üniversitesi Fen Bilimleri Enstitüsü Gıda Mühendisliği Anabilim Dalı Doktora tezi, Ankara, Türkiye, 165 s.

Kumar, V., Biswas, A.K., Sahoo, J., Chatli, M.K., Sivakumar, S. (2013). Quality and storability of chicken nuggets formulated with green banana and soybean hulls flours. J. Food Sci. Technol., 50(6): 1058-1068.

Leygonie, C., Britz, T.J. Hoffman, L.C. (2012). Impact of freezing and thawing on the quality of meat: review. Meat Sci., 91(2): 93-98.

Marques Pino, L., Cavaleiro, C., Conceição Castilho, Md., Bismara Regitano D'arce, M.A., Da Silva Torres, E.A., Ramos, F. (2013). The use of natural antioxidants (oregano and sage) to reduce hexanal production in precooked chicken during chill storage. Vitae 20(2): 105-110.

Mauriello, G., Casaburi, A., Blaiotta, G., Villani, F. (2004). Isolation and technological properties of coagulase negative staphylococci from fermented sausages of Southern Italy. Meat Sci., 67(1): 149-158.

Mielnik, M., Olsen, E., Vogt, G., Adeline, D., Skrede, G. (2006). Grape seed extract as antioxidant in cooked, cold stored turkey meat. LWT-Food Sci. Technol., 39(3): 191-198.

Missbach, B., Schwingshackl, L., Billmann, A., Mystek, A., Hickelsberger, M., Bauer, G., König, J. (2015). Gluten-free food database: the nutritional quality and cost of packaged glutenfree foods. PeerJ, 3: e1337.

Modi, V., Mahendrakar, N., Sachindra, N., Rao, D.N. (2004). Quality of nuggets prepared from fresh and smoked spent layer chicken meat. $J$. Muscle Foods, 15(3): 195-204.

Mukprasirt, A., Herald, T., Boyle, D., Boyle, E.A.E. (2001). Physicochemical and microbiological properties of selected rice flourbased batters for fried chicken drumsticks. Poultry Sci., 80(7): 988-996.

Niewinski, M.M. (2008). Advances in celiac disease and gluten-free diet. J. Am. Diet Assoc., 108(4): 661-672.

Özugur, G., Hayta, M. (2011). Tahıl esaslı glutensiz ürünlerin besinsel ve teknolojik özelliklerinin iyileştirilmesi. GID A, 36(5): 287294.

Pignoli, G., Bou, R., Rodriguez-Estrada, M., Decker, E.A. (2009). Suitability of saturated aldehydes as lipid oxidation markers in washed turkey meat. Meat Sci., 83(3): 412-416.

Pinkaew, P., Naivikul, O. (2019). Development of gluten-free batter from three Thai rice cultivars and its utilization for frozen battered chicken nugget. J. Food Sci. Technol., 56(8): 3620-3626.

Pourashouri, P., Shabanpour, B., Heydari, S., Raeisi, S. (2020). Encapsulation of fish oil by carrageenan and gum tragacanth as wall materials and its application to the enrichment of chicken nuggets. LWT-Food Sci. Tech.,137: 110334.

Reddy, D.M. (2017). Comparative effect of green tea extract and BHA on chicken meat nuggets during frozen storage. Chem. Sci. Rev. Lett., 6(21): 585-588.

Rodrigo, L. (2006). Celiac disease. World J. gastroenterol., 12(41): 6577-6584.

Ross, C.F., Smith, D.M. (2006). Use of volatiles as indicators of lipid oxidation in muscle foods. Compr. Rev. Food Sci. Food Safe., 5(1): 18-25.

Sampaio, G., Saldanha, T., Soares, R., Torres, E.A.F.S. (2012). Effect of natural antioxidant combinations on lipid oxidation in cooked 
chicken meat during refrigerated storage. Food Chem., 135(3): 1383-1390.

Santhi, D., Kalaikannan, A. (2014). The effect of the addition of oat flour in low-fat chicken nuggets. J. Nutr. Food Sci., 4(1): 260.

Serim, F. (1991). Bitkisel yağların farklı sıcaklık ve sürelerdeki oksidasyon düzeyinin spektrofotometrik yöntemlerle belirlenmesi. GID A, 16(2): 123-129.

Shih, F., Daigle, K. (1999). Oil uptake properties of fried batters from rice flour. J. Agric. Food Chem., 47(4): 1611-1615.

Sohaib, M., Anjum, F.M., Arshad, M.S., Imran, M., Imran, A., Hussain, S. (2017). Oxidative stability and lipid oxidation flavoring volatiles in antioxidants treated chicken meat patties during storage. Lipids Health. Dis., 16(1): 27.

Soncu, E.D. (2014). Kaplamalı tavuk ürünlerinde kızartma sırasında akrilamid oluşumunun incelenmesi. Ankara Üniversitesi Fen Bilimleri
Enstitüsü Gıda Mühendisliği Anabilim Dalı Doktora Tezi, Ankara, Türkiye, $152 \mathrm{~s}$.

Tamsen, M., Shekarchizadeh, H., Soltanizadeh, N., (2018). Evaluation of wheat flour substitution with amaranth flour on chicken nugget properties. LWT-Food Sci Tech.91: 580-587.

Tașbaș, H., Osanmaz, E., Özer, C.O., Kiliç, B. (2016). Quality characteristics and storage stability of gluten-free coated chicken nuggets. Carpathian J. Food Sci. Tech., 8(4): 91-103.

Utrera, M., Morcuende, D., Estévez, M. (2014). Temperature of frozen storage affects the nature and consequences of protein oxidation in beef patties. Meat Sci., 96(3): 1250-1257.

Verma, A.K., Rajkumar, V., Kumar, S. (2019). Effect of amaranth and quinoa seed flour on rheological and physicochemical properties of goat meat nuggets. J. Food Sci. Technol., 56(11): 5027-5035. 